\title{
Analisis Hukum terhadap Hak Imunitas Advokat Dalam Beracara Memberikan Bantuan Hukum
}

\author{
M. Rudi Hartono ${ }^{1 *}$, Radi Candra ${ }^{2}$ \\ ${ }^{1,2}$ Fakultas Hukum Universitas Batanghari \\ Jl. Sunan Bonang RT. 12, Kel. Simpang III Sipin, Kec. Kotabaru-Jambi \\ *Correspondence email: mrudihartono700@gmail.com, fitrishylviana16@gmail.com
}

\begin{abstract}
Abstrak. Keberadaan Advokat sebagai pencari keadilan pada masa sekarang ini sangat dibutuhkan dan penting dalam kehidupan bermasyarakat serta berbangsa seiring dengan meningkatnya kesadaran hukum serta kompleksnya permasalahan hukum didalam masyarakat. Advokat merupakan suatu profesi yang memberikan jasa hukum kepada masyarakat atau kliennya yang menghadapi masalah hukum, baik yang berhubungan dengan perkara pidana, perdata, maupun tata usaha negara. Jasa hukum yang diberikan Advokat dapat berupa konsultasi hukum, bantuan hukum, pemberi advice hukum, menjalankan kuasa, mewakili, mendampingi, membela, dan melakukan perbuatan hukum lainnya untuk dan atas nama klien. Dalam memberikan jasa hukum tersebut, seorang Advokat bisa melaksanakanyan melalui prodeo (Cuma -Cuma) atau memperoleh honorrium atau pembayaran jasa dari klien. Secara umum kedudukan advokat setara dengan penegak hukum lainnya seperti Hakim, Jaksa, serta Kepolisian. Dengan demikian advokat juga berperan penting dalam penegakkan dan perlindungan hukum bagi masyarakat. Peranan yang seharusnya dari advokat telah diatur dalam Undang-Undang Nomor 18 Tahun 2003 tentang Advokat.
\end{abstract}

Kata Kunci: Kekebalan; Hak; Advokat

\begin{abstract}
The existence of advocates as justice seekers at this time is very much needed and important in the life of the community and nation as well as increasing legal awareness and the complexity of legal problems in society. Advocacy is a profession that provides legal services to the public or its clients who face legal problems, both those related to criminal, civil and state affairs. Legal services provided by Advocates can be in the form of legal consultations, legal assistance, legal advice providers, exercising power, representing, assisting, defending, and performing other legal actions for and on behalf of clients. In providing these legal services, an Advocate can carry out it through a prodeo (Free of charge) or obtain an honorarium or payment for services from the client. In general, the position of an advocate is equal to that of other law enforcers such as the judges, prosecutors, and the police. : "Thus, advocates also play an important role in upholding and protecting the law for the community. The proper role of an advocate has been regulated in Law Number 18 of 2003 concerning "Advocates.
\end{abstract}

Keyword: Immunity, right, and Advocate

\section{PENDAHULUAN}

Advokat termasuk profesi mulia (officium nobile), karena didalam melaksanakan kewajiban dan pekerjaannya seorang Advokat menjadi fasilitator didalam menemukan sesuatu yang benar dan penegakkan keadilan demi membela Hak Asasi Manusia serta memberi pembelaan hukum yang memiliki sifat kebebasan serta kemandirian serta tidak melakukan pemihakan ataupun tidak pandang buluh terhadap lawan kliennya apakah golongan kuat, pejabat, penguasa, ataupun lainnya. Untuk mencapai hal tersebut maka seorang Advokat juga harus bertindak profesional, menjunjung tinggi kehormatan, keberanian, berkomitmen, berintegritas, hukum, keadilan, serta selalu menjunjung tinggi Janji Advokat, serta Kode Etik Profesi didalam melaksanakan kewajibannya sesuai dengan fungsi dan tugasnya. Oleh sebab itu, pada masa lalu, sekarang maupun di masa mendatang, profesi Advokat senantiasa akan mengambil posisi untuk memperjuangkan keadilan dan kebenaran. ${ }^{1}$

Perkataan "Advocaat" dilihat dari etimologi berasal dari bahasa Latin, yaitu "Advocare" yang berarti "to defend, to calls to one's aid to vouch or warant". Sedangkan didalam istilah kata Inggris "Advocatee" yang artinya : "to speaks in favours of or depend by argument, to supports, indicatee, or recommendeed publiclys". ${ }^{2}$ Advokat secara terminologi, memiliki arti seseorang ahli hukum yang memberi bantuan ataupun pertolongan didalam persoalan hukum. ${ }^{3}$

Bantuan atau pertolongan ini bersifat memberikan nasehat - nasehat sebagai jasa baik, didalam perkembangan selanjutnya bisa dimintakan oleh siapa saja yang memerlukan, membutuhkannya untuk beracara didalam hukum. Jasa hukum ialah jasa yang diberi oleh Advokat berwujud memberi konsultasi

\footnotetext{
${ }^{1}$ Frans Hendra Winarta, 1995, Advokat Indonesia Citra, Idealisme dan Keprihatinan, Pustaka Sinar Harapan, Jakarta, hlm. 15

${ }^{2}$ Frans Hendra Winarta, Advokat Indonesia, Cita, Idealisme, dan Keprihatinan, Sinar Harapan, Jakarta, 1995. Hlm. 72.

${ }^{3}$ Lasdin Wlas, 1989, Cakrawala Advokat Indonesia, Yogyakarta: Liberty Yogyakarta.hal.3
} 
hukum, melaksanakan kuasa, mewakili, mendampingi, membela, dan melaksanakan perbuatan hukum lainnya untuk kepentingan hukum kliennya.$^{4}$

Pada waktu memberi bantuan hukum pada klien yang membuat sesuatu tindak pidana, maka seorang Advokat harus berpedoman pada Kode Etik Advokat Indonesia dan Undang-Undang Republik Indonesia Nomor 18 Tahun 2003 Tentang Advokat serta peraturan rundang-undang lain yang mengatur mengenai Advokat. Kentuan itu ditujukan agar peranan Advokat didalam memberikan usaha pembelaan bagi kliennya yang disangka telah melakukan tindak pidana tetap didasarkan pada rasa keadilan dan kebenaran. Faktanya sampai sekarang ini masih ditemukan Advokat yang kadang tidak korperatif didalam usaha menegakan hukum, prilaku Advokat seperti ini yang memperlihatkan bahwa masih terdapat adanya Advokat yang belum menjunjung tinggi profesionalisme dan idealism advokat.

Akan tetapi faktanya didalam kehidupan masyarakat profesi Advokat kadang jadi bias oleh sebagian pandangan masyarakat, khususnya yang berhubungan dengan peranan Advokat didalam memberi jasa bantuan hukum. Terdapat sebagian orang yang beranggapan pada profesi Advokat sebagai profesi yang terkadang memutarbalikan suatu kebenaran atau kenyataan. Profesi advokat dipandang sebagai pekerjaan bagi seorang yang tidak memiliki hati nurani, oleh sebab selalu membela seseorang atau mereka yang melakukan suatu kejahatan, serta memperoleh kesenangan diatas kesusahan bagi orang lain.

Adanya profesi Advokat di Indonesia sebagai "agents of law developmentt" agen pembangunan hukum terlebih menjadi "agents of law enculturations" agen membudidayakan hukum bagi masyarakat tidak sebaliknya sebagai "agent of law commercialization" agen komersialisasi hukum dalam memberikan jasa hukum. ${ }^{5}$

Didalam memakai jasa Advokat, adalah suatu kebutuhan atas rasa kesadaran hukum sendiri ataupun karena sebab peranan Advokat yang terlampau agresif didalam memberikan pengaruh bagi klien dalam berperkara pada pengadilan untuk kepentingan Advokat. Didalam perkembangan selanjutnya diperlukan peningkatkan rasa sadar hukum untuk tegaknya suatu kebenaran, keadilan yang tidak diskriminatif. Memberikan jasa bantuan hukum yang dikhususkan pada seseorang yang mempuyai kaitan erat dengan "equality before the law" (persamaan didalam hukum) serta "access to legals councell" (media akses legal dipersidangan) yang memberikan jaminan "justice for all" keadilan bagi semua orang. ${ }^{6}$

Guna menghindarkan supaya tulisan penelitian jurnal yang penulis lakukan, tidak jauh menyimpang pada rumusan masalah yang diinginkan, untuk itu didalam penulisan ini maka penulis memberikan batasan-batasan dalam permasalahan-permasalahan yang akan dibahas yang mencakup beberapa hal dibawah ini :

1. Bagaimana pengaturan hak imunitas yang dimiliki oleh Advokat menurut Undang-Undang Republik Indonesia Nomor 18 Tahun 20003 ?

2. Bagaimana pelaksanaan hak imunitas Advokat dalam beracara memberikan bantuan hukum ?

\section{METODE}

\section{Pendekatan Penelitian}

Pendekatann penelitian yang dipakai didalam penelitian ini secara Sosio Legal Research, yaitu penelitian dengan memperhatikan implementasi hukum ataupun peraturan undang-undang yang berlaku didalam kehidupan sosial masyarakat. ${ }^{7}$ Didalam hal ini untuk mengetahui dan memahami bagaimana peraturan undang-undang tersebut diterapkan didalam pelaksanaan hak imunitas Advokat dalam beracara memberikan bantuan hukum.

\section{Spesifikasi Penelitian}

Spesifikasi Penelitian yang bersifat deskriptif analisis, yaitu memberikan gambaran dan analisa pada suatu kejadian hukum yang terjadi dengan menggambarkan peristiwa-peristiwa yang ada, ${ }^{8}$ didalam hal ini berhubungan dengan penelitian tentang pelaksanaan hak-hak imunitas Advokat didalam beracara memberi jasa bantuan hukum.

\footnotetext{
${ }^{4}$ Undang-Undang Republik Indonesia Nomor 18 Tahun 2003 tentang “Advokat” Pasal 1 Ayat (2).

${ }^{5}$ A. Rahmat Rosyadi, dan Hartini Sri, Advokat Didalam Perspektif Islam dan Hukum Positif, Ghalia Indonesia, Jakarta,
} 2003. Hlm. 18

${ }^{6}$ Ibid., Hlm. 19.

${ }^{7}$ J. Supranto, Metode Penelitian Hukum dan Statistik, cet. Ke-1, (Jakarta :Rhineka Cipta, 2003), hal.21.

8 Ibid., 


\section{Sumber Data}

Untuk memperoleh data serta informasi yang dibutuhkan didalam menyusun penelitian ini, didapatkan melalui data Primer dengan cara melakukan penelitian kepustakaan (Library Research) terhadap:

1. Bahan Hukum Primer

Yakni merupakan bahan hukum yang mengikat berupa peraturan undang-undang yang berkaita dengan permasalahan yang diteliti seperti :

a. Undang-Undang Nomor 8 tahun 1981 tentang Kitab Undang-undang Hukum Acara Pidana (KUHAP) ,

b. Undang-Undang Republik Indonesia Nomor 18 Tahun 2003 Tentang Advokat ,

2. Bahan Hukum Skunder

Yakni bahan hukum yang berupa kajian pada buku, koran, tulisan-tulisan ilmiah seperti makalah, literatur hukum, jurnal hukum, majalah, artikel dan bahan tertulis yang lain memiliki hubungan dengan permasalahan yang diteliti .

3. Bahan Hukum Tertier

Yakni bahan hukum yang memberi suatu penjelasan pada bahan hukum primer serta bahan hukum skunder, berupa Kamus Hukum .

\section{Analisa Data}

Data-data primer yang penulis peroleh didalam kepustakaan, kemudian dikumpulkan untuk selanjutnya disusun, diolah, serta diklasifikasikan kedalam bagian yang tertentu, untuk diolah selanjunya dianalisis. Analisis data yang dipergunakan didalam penelitian ini memiliki sifat analisis kualitatif, yaitu suatu analisa dengan menelaah semua hasil data mengenai hak imunitas Advokat dalam beracara memberikan bantuan hukum yang selanjutnya disajikan didalam bentuk uraian didalam pembahasan ini.

\section{HASIL DAN PEMBAHASAN}

\section{Pengaturan hak imunitas yang dimiliki oleh Advokat menurut Undang-Undang Republik Indonesia Nomor 18 Tahun 20003}

Pemberian jasa bantuan hukum pada masyarakat sebagai klien yang tersangkut permasalahan hukum pada hakekatnya adalah tugas utama advokat. Advokat yang ditunjuk menerima perintah ataupun order maupun kuasa dari klien didasarkan perikatan yang bebas, yang dibuat secara tertulis, atau tidak tertulis, yang tunduk kepada Kode Etik Profesi Advokat, tidak tunduk terhadap kekuasaan politik, yang memiliki kewajiban serta tanggung jawab publik.

Didalam proses menegakan hukum dalam persidangan melibatkan banyak lembaga yang satu dengan lainnya memiliki wewenang yang berbeda. Lembaga yang dimaksudkan diantaranya advokat. Dalam memberi jasa bantuan hukum, yang mana ketika melaksanakan tugas dan fungsinya dapat berperan sebagai pendamping, pemberi pendapat hukum atau menjadi kuasa hukum untuk dan atas nama kliennya dalam rangka menegakkan hukum, keadilan, dan kebenaran ${ }^{9}$

Oleh sebab itu Advokat harus mampu untuk mengidenifikasi suatu peristiwa dengan mempergunakan ilmu pengetahuan hukum materiil dan hukum formilnya; begitu pula Advokat mengetahui batas kewenangannya. Pengaturan semacam ini untuk menjamin hak-hak klien dalam penyidikan .

Beberapa pasal dalam Undang-undang ini hanya memberikan kekebalan terhadap Advokat dalam menjalankan profesinya dengan "itikad baik". Dalam hal ini dibuktikan bahwa Advokat tersebut dalam menjalankan profesinya tidak dengan itikad baik, yang bersangkutan dapat dituntut baik secara perdata maupun pidana.

Undang-Undang Advokat mengakui hak imunitas secara sangat terbatas. Terdapat 2 (dua) macam hak imunitas yang diberikan Undang-Undang Advokat kepada para Advokat yaitu: Hak Imunitas di luar sidang pengadilan dan Hak imunitas didalam sidang pengadilan (di setiap lingkungan dan tingkat pengadilan).

Pengaturan mengenai hak imunitas dan malpraktek Advokat dalam Undang-Undang No. 18 Tahun 2003. Hak imunitas dalam Pasal 14 dari Undang- Undang Advokat, yang menentukan sebagai berikut:

"Advokat bebas mengeluarkan pendapat atau pernyataan dalam membela perkara yang menjadi tanggung jawabnya di dalam sidang pengadilan dengan tetap berpegang pada kode etik profesi dan peraturan perundangundangan." 
Penjelasan resmi atas Pasal 14:

"Yang dimaksud dengan "bebas" adalah tanpa tekanan, ancaman, hambatan tanpa rasa takut, atau perlakuan yang merendahkan martabat profesi. Kebebasan tersebut dilaksanakan sesuai dengan kode etik profesi dan peraturan perundang-undangan."

Pasal 15:

"Advokat bebas dalam menjalankan tugas profesinya untuk membela perkara yang menjadi tanggung jawabnya dengan tetap berpegang pada kode etik profesi dan peraturan perundang-undangan."

Penjelasan resmi atas Pasal 15 :

"Ketentuan ini mengatur mengenai kekebalan Advokat dalam menjalankan tugas profesinya untuk kepentingan kliennya di luar sidang pengadilan pengadilan dan dalam mendampingi kliennya pada dengar pendapat di lembaga perwakilan rakyat."

Pasal 16:

"Advokat tidak dapat dituntut baik secara perdata maupun pidana dalam menjalankan tugas profesinya dengan iktikad baik untuk kepentingan pembelaan klien dalam sidang pengadilan."

Penjelasan resmi atas Pasal 16 :

"Yang dimaksud dengan "iktikad baik" adalah menjalankan tugas profesi demi tegaknya keadilan berdasarkan hukum untuk membela kepentingan kliennya. Yang dimaksud dengan "sidang pengadilan" adalah sidang pengadilan dalam setiap tingkat pengadilan di semua lingkungan peradilan.”

Pasal 17:

"Dalam menjalankan profesinya, Advokat berhak memperoleh informasi, data, dan dokumen lainnya, baik dari instansi Pemerintah maupun pihak lain yang berkaitan dengan kepentingan tersebut yang diperlukan untuk pembelaan kepentingan Kliennya sesuai dengan peraturan perundangundangan."

Pasal 18:

"(2) Advokat tidak dapat diidentikkan dengan Kliennya dalam membela perkara Klien oleh pihak yang berwenang dan/atau masyarakat."

Pasal 18 ayat (2) dari Undang-Undang Advokat menentukan dengan jelas bahwa, Advokat tidak dapat diidentikkan dengan kliennya dalam membela perkara klien oleh pihak yang berwenang dan/atau masyarakat.

Advokat wajib merahasiakan segala sesuatu yang diketahui atau diperoleh dari kliennya karena hubungan profesinya. Advokat berhak atas kerahasiaan hubungannya dengan klien, termasuk perlindungan atas berkas dan dokumennya terhadap penyitaan atau pemeriksaan dan perlindungan terhadap penyadapan atas komunikasi elektronik Advokat.

Pasal 19:

“(2) Advokat berhak atas kerahasiaan hubungannya dengan Klien, termasuk perlindungan atas berkas dan dokumennya terhadap penyitaan atau pemeriksaan dan perlindungan terhadap penyadapan atas komunikasi elektronik Advokat."

Pengaturan mengenai hak imunitas dan pelanggaran Advokat dalam Organisasi Advokat juga tertuang melalui Kode Etik Advokat Indonesia. Pengaturan hak dan kewajiban dalam Pasal 3:

a. "Advokat dapat menolak untuk memberi nasihat dan bantuan hukum kepada setiap orang yang memerlukan jasa dan atau bantuan hukum dengan pertimbangan oleh karena tidak sesuai dengan keahliannya dan bertentangan dengan hati nuraninya, tetapi tidak dapat menolak dengan alasan karena perbedaan agama, kepercayaan, suku, keturunan, jenis kelamin, keyakinan politik dan atau kedudukan sosialnya.

$b$. Advokat dalam melakukan tugasnya tidak bertujuan semata-mata untuk memperoleh imbalan materi tetapi lebih mengutamakan tegaknya Hukum, kebenaran dan keadilan.

c. Advokat dalam menjalankan profesinya adalah bebas dan mandiri serta tidak dipengaruhi oleh siapapun dan wajib memperjuangkan hak-hak azasi manusia dalam Negara Hukum Indonesia.

d. Advokat wajib memelihara rasa solidaritas diantara teman sejawat.

$e$. Advokat wajib memberikan bantuan dan pembelaan hukum kepada teman sejawat yang diduga atau didakwa dalam suatu perkara pidana atas permintaannya atau karena penunjukan organisasi profesi. 
f. Advokat tidak dibenarkan untuk melakukan pekerjaan lain yang dapat merugikan kebebasan, derajat dan martabat Advokat.

g. Advokat harus senantiasa menjungjung tinggi profesi Advokat sebagai profesi terhormat (officium nobile).

$h$. Advokat dalam menjalankan profesinya harus bersikap sopan terhadap semua pihak namun wajib mempertahankan hak dan martabat Advokat.

$i$. Seorang Advokat yang kemudian diangkat untuk menduduki suatu Jabatan Negara (Eksekutif, Legislatif dan Yudikatif) tidak dibenarkan untuk berpraktek sebagai Advokat dan tidak diperkenankan namanya dicantumkan atau dipergunakan oleh siapapun atau oleh kantor manapun dalam suatu perkara yang sedang diproses berjalan selama ia menduduki jabatan tersebut."

Berkaitan dengan hal tersebut diatas, advokat dalam bertindak sedapatnya harus menghindarkan diri dari pelanggaran profesinya yang tersirat dalam hubungan antara Advokat dan klien. Hal ini dikarenakan berawal dari terjadinya pelanggaran Kode Etik Profesi yang dilakukan oleh diri Advokat dalam membela kepentingan klien, maka tidak tertutup kemungkinan pelanggarannya akan kemudian disertai tindak pidana. Pelanggaran kode etik dalam Pasal 4 Kode Etik Advokat Indonesia :

a. "Advokat dalam perkara-perkara perdata harus mengutamakan penyelesaian dengan jalan damai.

b. Advokat tidak dibenarkan memberikan keterangan yang dapat menyesatkan klien mengenai perkara yang sedang diurusnya.

c. Advokat tidak dibenarkan menjamin kepada kliennya bahwa perkara yang ditanganinya akan menang.

d. Dalam menentukan besarnya honorarium Advokat wajib mempertimbangkan kemampuan klien.

e. Advokat tidak dibenarkan membebani klien dengan biaya-biaya yang tidak perlu.

f. Advokat dalam mengurus perkara cuma-cuma harus memberikan perhatian yang sama seperti terhadap perkara untuk mana ia menerima uang jasa.

g. Advokat harus menolak mengurus perkara yang menurut keyakinannya tidak ada dasar hukumnya.

h. Advokat wajib memegang rahasia jabatan tentang hal-hal yang diberitahukan oleh klien secara kepercayaan dan wajib tetap menjaga rahasia itu setelah berakhirnya hubungan antara Advokat dan klien itu.

i. Advokat tidak dibenarkan melepaskan tugas yang dibebankan kepadanya pada saat yang tidak menguntungkan posisi klien atau pada saat tugas itu akan dapat menimbulkan kerugian yang tidak dapat diperbaiki lagi bagi klien yang bersangkutan, dengan tidak mengurangi ketentuan sebagaimana dimaksud dalam pasal 3 huruf a.

j. Advokat yang mengurus kepentingan bersama dari dua pihak atau lebih harus mengundurkan diri sepenuhnya dari pengurusan kepentingan-kepentingan tersebut, apabila dikemudian hari timbul pertentangan kepentingan antara pihak-pihak yang bersangkutan.

k. Hak retensi Advokat terhadap klien diakui sepanjang tidak akan menimbulkan kerugian kepentingan klien.”

Berdasarkan hal tersebut, maka seorang advokat didalam bertindak sudah seharusnya menjunjungi tinggi kode etik profesi advokat yang dimiliki, meskipun didalam beracara advokat dilindungi oleh Undang-Undang Advokat dan memiliki hak imunitas untuk menjalankan tugas dan kewajibannya membela kepentingan klien, namun dalam beracara seorang advokat harus mampu menghindarkan diri dari tindakan-tindakan yang dapat menimbulkan kesalahan atau pelanggaran nantinya.

\section{Pelaksanaan hak imunitas Advokat dalam beracara memberikan bantuan hukum}

Mengenai pelaksanaan hak-hak imunitas yang dimiliki oleh seorang advokat sebagaimana yang telah diatur didalam Undang-Undang Nomor 18 Tahun 2003 tentang Advokat, maka hak-hak imunitas dari seorang advokat dalam beracara memberikan bantuan hukum dapat dibagi menjadi 2 (dua) bagian, yakni :

\section{Hak Imunitas di Dalam Sidang Pengadilan}

Hak imunitas seorang advokat didalam beracara pada saat persidangan di pengadilan, terdiri dari beberapa bentuk hak imunitas sebagaiman diatur didalam Pasal 14 dan Pasal 16 dari Undang-Undang Advokat, yakni

1. Hak Bebas mengeluarkan pendapat atau pernyataan.

2. Pendapat atau pernyataan tersebut dilakukan di dalam pengadilan di semua lingkungan dan tingkatan.

3. Hak tidak mendapatkan tekanan, ancaman, hambatan, rasa takut dan merendahkan martabat profesi advokat didalam berpendapat atau pernyataan

4. Hak mempertanggungjawabkan semua Pendapat atau pernyataan dikeluarkan dalam menjalankan perkara yang menjadi tanggung jawab seorang advokat.

5. Hak melakukan kuasa penuh mewakili diri klien didalam mendampingi dan beracara di persidangan,

6. Hak tidak dapat dituntut secara perdata maupun pidana, selama tidak melanggar seorang advokat tidak melanggar kode etik profesi advokat; 


\section{Hak Imunitas di Luar Sidang Pengadilan}

Mengenai Hak imunitas yang dimiliki oleh seorang Advokat dalam melaksanakan tugas dan tanggungjawabnya membela kepentingan klien di luas proses persidangan di Pengadilan diatur dalam Pasal 15 Undang-Undang Nomor 18 Tahun 2003 tentang Advokat, yang terdiri dari beberapa bentuk sebagai berikut:

1. Hak Kebebasan lebih luas, yaitu kebebasan dalam menjalankan tugas profesi untuk menjalankan perkara, tidak hanya kebebasan dalam mengeluarkan pendapat atau pernyataan.

2. Hak untuk tetap terus mendampingi klien didalam maupun diluar proses persidangan pada kegiatan tertentu,

3. Hak untuk tidak dapat dituntut secara perdata maupun pidana, meskipun jaminan kebebasan tersebut mempunyai konsekuensi logis juga terhadap tidak dapat dituntutnya Advokat secara perdata maupun pidana.

Dalam kode etik hak imunitas Advokat dibatasi dengan Pasal 3 Kode Etik Profesi Advokat. Seorang Advokat dianggap memiliki hak imunitas (kekebalan) di saat Advokat bekerja atau menjalankan tugasnya. Berpedoman pada pengertian "original intend"; bunyi asli Undang-Undang No.18 Tahun 2003 tentang Advokat Pasal 16, imunitas itu hanya berlaku pada saat persidangan, karena di dalam penjelasannya tegas dikatakan bahwa pengertian persidangan itu adalah pada tingkatan, Pengadilan Negeri, Pengadilan Tinggi dan Mahkamah Agung.

Sesungguhnya jika mengacu pada undang-undang tersebut imunitas yang diberikan tidaklah cukup. Mengingat tugas dan tanggung jawab Advokat bukan hanya pada saat persidangan. Melainkan 24 jam selama Advokat bekerja membela atau mewakili kepentingan kliennya. Barangkali pada saat undang-undang itu dibuat tidak pernah terpikir bahwa profesi Advokat juga sama dan sederajat dengan Polisi, Hakim Dan Jaksa, maklum dari catatan yang ada. Di mana mereka punya imunitas dalam pekerjaan sehingga tidak was-was atau khawatir dianggap melanggar hukum saat bekerja.

Asas "legalitas" yang diadopsi KUHP kita dalam pasal 1 ayat (1). Tegas menyebutkan bahwa tidak bisa dipidana seseorang jika tidak ada aturan yang melarang sebelumnya atas perbuatan hukum seseorang. Artinya, perbuatan pidana seseorang hanya bisa dihukum jika perbuatan yang disangkakan itu sudah diatur dalam sebuah undang-undang yang sudah ada sebelum perbuatan itu terjadi.

Hak Imunitas Advokat yang dijamin Undang-Undang karena dalam membela kepentingan klien Advokat tidak boleh dihinggapi rasa takut dan harus membela dengan rasa aman, dilindungi oleh negara c.q. pemerintah dalam melaksanakan pekerjaannya dan pembelaan separuh hati akan merugikan kepentingan klien yang dibela. Atas dasar itulah Advokat diberi perlindungan berupa imunitas.

Imunitas Advokat yang dijamin dalam Undang-Undang Advokat akhir-akhir ini sering kali disalah artikan, bahwa semua tindakan Advokat untuk membela klien dibenarkan dan tidak dapat dituntut secara hukum. Namun, memalsu bukti, menghina, memfitnah, dan perbuatan lain yang dilarang hukum tentu saja tidak imun/kebal dari tuntutan hukum.

Seorang Advokat tentu saja tidak bisa diidentikkan dengan perbuatan hukum klien atau orang yang dibelanya, terkecuali ia menjadi bagian dari kejahatan itu misalnya Advokat ikut menyogok dan mengantar uang suap atau membantu untuk melarikan diri.

Jika Advokat diperiksa oleh Polisi, sepanjang pemeriksaan itu terkait dengan pekerjaan atau profesinya, maka Polisi baru bisa bertindak jika sebelumnya telah meminta keterangan dari Organisasi Advokat tentang sah dan tidaknya pekerjaan seorang Advokat. Advokat memiliki hak imunitas (kekebalan). Karena itu, dalam membela kliennya, tidak selamanya Advokat begitu saja digugat oleh pihak ketiga atau ditangkap/ditahan oleh pihak yang berwajib. Seperti juga jaksa dan hakim mempunyai hak imunitas dalam menjalankan tugasnya.

Apabila di analogikan Advokat yang diadukan/dilaporkan menipu kliennya karena kliennya kalah. Yang pertama sebelum polisi memeriksa Advokat, klien mesti meminta Organisasi Advokat tersebut menjelaskan apakah yang dilakukan seorang Advokat tersebut sesuai standar profesi atau tidak. Sehingga perbuatan tersebut termasuk kategori penipuan atau pelanggaran etika profesi.

Misalnya Advokat diadukan karena memberikan janji bahwa perkara yang ditangani sudah pasti menang. Jika Advokat yang bersangkutan sudah diperiksa Dewan Kehormatan Advokat dan ditemukan kesalahannya maka hukumannya dua. Oleh Organisasi Advokat bisa dijatuhi sanksi administrasi bahkan dipecat dan memperoleh sanksi pidana dari penegak hukum. Namun jika tidak ditemukan bukti dalam pemeriksaan Dewan Kehormatan tentang apa yang diadukan, maka ia tidak bisa diproses pidana.

Didalam prakteknya menjalankan tugas dan tanggungjawab, seorang advokat menpunyai Hak untuk menyimpan rahasia klien, yakni rahasia-rahasia yang memenuhi syarat-syarat sebagai berikut :

1. Rahasia tersebut merupakan informasi yang substansial dan penting bagi klien atau bagi pembelanya.

2. Rahasia tersebut sebelumnya belum pernah terbuka untuk umum secara meluas. Apabila rahasia tersebut telah terbuka untuk umum tetapi belum meluas, atau jika rahasia tersebut sudah dibuka oleh advokat kepada orang lain.

3. Rahasia tersebut bukanlah informasi yang memang tersedia untuk publik (publik information).

4. Rahasia yang jika dibuka akan menimbulkan rasa malu bagi klien, Advokat atau pihak-pihak lainnya. 
5. Rahasia yang jika dibuka akan merugikan kepentingan kliennya.

6. Rahasia yang jika dibuka akan mempersulit pembelaan Advokat terhadap kliennya.

7. Rahasia yang jika dibuka akan menimbulkan kemungkinan klien tidak lagi memberikan informasi selanjutnuya kepada Advokat. Hal tersebut akan mempersulit advokat dalam melakukan pembelaannya.

8. Bagi klien, informasi tersebut sangat penting dan atau sensitif.

9. Jika dibuka rahasia tersebut, akan menimbulkan kemarahan/gejolak/atau sikap masyarakat yang merugikan kepentingan klien dan atau merugikan kepentingan pembelaan.

Advokat dalam berperkara membela kliennya dilarang untuk membocorkan rahasia kliennya. Advokat pun tidak boleh menggunakan rahasia kliennya untuk merugikan kepentingan klien tersebut. Advokat tidak boleh menggunakan rahasia kliennya untuk kepentingan pribadi Advokat atau untuk kepentingan pihak ketiga.

Sesuai Pasal 19 Undang-Undang No. 18 Tahun 2003, dan Kode Etik Profesi Advokat Pasal 4 huruf (h):

"Advokat wajib memegang rahasia jabatan tentang hal-hal yang diberitahukan oleh klien secara kepercayaan dan wajib tetap menjaga rahasia itu setelah berakhirnya hubungan antara Advokat dan klien itu."

Dalam berperkara menggunakan biaya-biaya tidak perlu hingga memberatkan kliennya. Akan tetapi hak ini hanya dapat digunakan para Advokat sebagai pengecualian.

\section{SIMPULAN}

1. Pengaturan mengenai hak imunitas profesi advokat dalam Undang-Undang Nomor 18 Tahun 2003 yakni Hak imunitas dalam Pasal 14 dari Undang- Undang Advokat, mengenai kebebasasn mengeluarkan pendapat atau pernyataan dalam membela perkara, Pasal 15: mengenai kebebasan dalam menjalankan tugas profesinya, Pasal 16: Advokat tidak dapat dituntut baik secara perdata maupun pidana, Pasal 17: Advokat berhak memperoleh informasi, data, dan dokumen lainnya, Pasal 18 ayat (2) : Advokat tidak dapat diidentikkan dengan Kliennya dalam membela perkara Klien oleh pihak yang berwenang dan/atau masyarakat, Pasal 19: ayat (2) Advokat berhak atas kerahasiaan hubungannya dengan Klien.

2. Pelaksanaan hak imunitas Advokat dalam beracara memberikan bantuan hukum saat melaksanakan tugas dan tanggungjawabnya, para advokat dilindungi dan diberikan hak imunitas untuk melakukan perbuatan-perbuatan hukum mengatasnamakan kepentingan klien. Sepanjang tidak melakukan perbuatan-perbuatan yang dilarang oleh hukum dan tidak melakukan kesalahan yang dapat menimbulkan indikasi suatu tindak pidana bagi diri advokat.

\section{DAFTAR PUSTAKA}

A. Rahmat Rosyadi, dan Hartini Sri, Advokat Dalam Perspektif Islam dan Hukum Positif, Ghalia Indonesia, Jakarta, 2003.

Frans Hendra Winarta, 1995, Advokat Indonesia Citra, Idealisme dan Keprihatinan, Pustaka Sinar Harapan, Jakarta.

J. Supranto, Metode Penelitian Hukum dan Statistik, cet. Ke-1, (Jakarta:Rineka Cipta, 2003)

Lasdin Wlas, 1989, Cakrawala Advokat Indonesia, Yogyakarta: Liberty Yogyakarta.

Rapaun Rambe, Teknik Praktek Advokat, PT. Grasindo, Jakarta, 2003.

Undang-Undang Republik Indonesia Nomor 18 Tahun 2003 tentang "Advokat" 